\title{
Possibility of using three invasive non-forest tree species as an alternative source for energy production
}

\author{
Ibrahim M. Aref ${ }^{1} \cdot$ Mohamed Z. Salem $^{2} \cdot$ Nader D. Shetta ${ }^{1,2} \cdot$ Thobayet S. Alshahrani $^{1}$. \\ Ramadan A. Nasser ${ }^{1,2}$
}

Received: 22 May 2016/Accepted: 5 November 2016/Published online: 24 December 2016

(C) The Japan Wood Research Society 2016

\begin{abstract}
Non-woody biomass species have high-energy potentials, which could be used for bioenergy production. Invasive species are species spreading into areas, where they are not native, consequently causing environmental and economic problems. Therefore, the present study evaluated the proximate, ultimate, chemical, and fuel characteristics of wood and charcoal of three invasive nonforest tree species in Saudi Arabia: Calotropis procera, Rhazya stricta, and Phragmites australis, which were compared with the wood of Acacia tortilis, a preferable local fuelwood. All these data were discussed to investigate the possibility of using the invasive plants for energy production. The thermal behavior of wood was analyzed using thermo-gravimetric and derivative thermo-gravimetric methods. Overall, compared with the wood of $A$. tortilis, the woods of $R$. stricta and $P$. australis are suitable for energy production. The charcoal produced from $P$. australis emitted less nitrogen $(\mathrm{N})$ oxide than that of $R$. stricta.
\end{abstract}

Keywords Invasive species - Charcoal · Fuelwood . Energy production

Ramadan A. Nasser

nasser67@ksu.edu.sa

1 Plant Production Department, Food and Agricultural Sciences College, King Saud University, Riyadh 11451, Saudi Arabia

2 Forestry and Wood Technology Department, Faculty of Agriculture (El-Shatby), Alexandria University, Alexandria 2154, Egypt

\section{Introduction}

Invasive species are "species spreading into areas, where they are not native" [1], and consequently cause environmental and economic problems [2]. The most important characteristics for invasive plants to dominate new habitats are efficient germination, high fecundity, early flowering, self-compatibility, production of large numbers of seeds, highly competitive, efficient carbon assimilation, rapid growth rates, effective dispersal, acclimation capacity, and vegetative reproduction [3].

Distributions of invasive plants vary globally, where large continents have a wide range of habitat-both dry and wet-that enhance the ability of the species to invade. For example, Calotropis procera is invasive in Caatinga and Restinga, Brazil [4], and Australia [5]; in wet habitats in the eastern, midwestern, and Mississippi River Delta regions of the United States, Phragmites australis has been very invasive [6]; and in extremely dry desert habitats in Saudi Arabia, Rhazya stricta is invasive [7].

The management of invasive species includes various measures. Some invasive plants may be grown in demarcated areas, provided a permit has been issued and steps are taken to prevent their spread. Many governments support the effort to add value to the clearing process instead [8]. Controlling invasive species, including mechanical, chemical, and biological methods, are expensive, and some have irreversible impacts on ecosystems when they are burnt on site, which causes a negative impact on the environment [8]. Controlling the spread of invasive plants through their reduction rather than eradication could provide a sustainable income source and job opportunities for local communities [9].

Wood harvested from natural forests has been the first and most important source of fuel used by humans for 
thousands of years. Increasing concern for the environment and climate change has resulted in significant reductions in wood harvest from national forests [10]; therefore, with increasing wood demand, there is a national and global shortage of fuelwood.

Research has focused on alternative fuel sources to overcome the fuel-wood shortage and avoid the dependence on crude oil, as well as to reduce $\mathrm{CO}_{2}$ emissions [11]. A wide variety of biomasses have been investigated for energy production, i.e., tobacco stems [12], rice waste [13], switch grass, coffee weed [14], vine pruning [15], date palm seeds [16], and date palm midribs [17].

Among some non-woody materials that have not yet been assessed as alternative raw materials for fuel-wood production, is the wood from invasive plants distributed throughout the kingdom. Using these plants, especially in arid and semi-arid areas, for energy production is a very attractive and a potentially viable economic and ecological alternative. However, there has been limited research on the use of invasive plants for fuel production.

C. procera (Ait) is a spreading, evergreen, perennial shrub, or small tree growing to $4 \mathrm{~m}$, and has few branches and leaves. Its native range includes southwest Asia and Africa in arid and semi-arid regions [18]. C. procera has been used as a source of many products, including fiber, rubber, and pulp, and paper [19, 20]. C. procera is widely distributed throughout Saudi Arabia, growing in open, dry habitats with little competition. Nasser et al. [20] predicted that the branch yield of the plant (oven-dry basis) is about $5.41 \mathrm{t} \mathrm{ha}^{-1}$.

R. stricta Decne, locally known as Harmal, is an evergreen, perennial shrub. It is a small, glabrous, erect shrub and branched from the base to a height of approximately $115 \mathrm{~cm}$, and then approximately to about $235 \mathrm{~cm}$ with a smooth central stem and dense semi-erect branches [21]. It is widely distributed in the sandy plains of Saudi Arabia and throughout western Asia from the Arabian Peninsula and Yemen to the North West Province of India, and is abundant in various regions of Pakistan [22]. R. stricta, characterizes the habitat of Saudi Arabia, is considered one of the most important medicinal plants that grow in most desert areas in the Arabian Peninsula [23]. However, $R$. stricta is unpalatable to animals, and has been invaded large areas of overgrazed rangelands in Saudi Arabia [24].

The common reed ( $P$. australis) is a large perennial grass producing tall and hollow stems. It is one of the most widely distributed vascular plants globally [25]. P. australis grows up to $6 \mathrm{~m}$ high in dense stands with long, flat leaves spread out widely from the stem. It is found in wetlands throughout temperate and tropical regions of the world, which grows efficiently on the shores of streams, lakes, and ponds, as well as in shallow water, ditches, and aquatic wastelands [25]. In all regions of Saudi Arabia, $P$. australis is widely distributed in aquatic habitats [26]. In aquatic habitats in the eastern Atlantic, Midwest, and Mississippi River Delta regions of the United States, as well as parts of the Pacific Northwest, $P$. australis has been very invasive $[6,27,28]$. The aboveground biomass yield of $P$. australis varies between 4 and $12.6 \mathrm{t} \mathrm{ha}^{-1}$ with an average of $7.4 \mathrm{t} \mathrm{h}^{-1}$ year $^{-1}$.

Accordingly, using invasive plants for energy will help to clear the existing stock of plants, which present a serious problem on farmland and rangeland [7]. In Saudi Arabia, the abundance and range of $C$. procera, $P$. australis, and $R$. stricta have increased, necessitating effective management to avoid a negative impact on the ecosystem and environment. In these invasive species with rapid growth rates and vegetative reproduction, they are potentially useful as energy crops. The use of these species as energy crops would be an innovative way to manage the wastes of invasive plants as an alternative raw material for energy production. Therefore, the aim of the present study was to evaluate the potential of $C$. procera, $P$. australis, and $R$. stricta as energy crops to control their invasion into other habitats.

\section{Materials and methods}

\section{Invasive species and sample preparation}

Woody samples were collected from three invasive species grown in the Agricultural Experimental Station $\left(24^{\circ} 6^{\prime} \mathrm{N}\right.$, $\left.46^{\circ} 5^{\prime} \mathrm{E}\right), 60 \mathrm{~km}$ south of Riyadh, Saudi Arabia during December 2014. The invasive plants sampled were $C$. procera, $R$. stricta, and $P$. australis. The environmental factors of the study site included a temperature range of $10{ }^{\circ} \mathrm{C}$ in winter to $41^{\circ} \mathrm{C}$ in summer, $50 \mathrm{~mm}$ annual rainfall, and calcareous soil. A. tortilis wood collected from natural indigenous forest in the El-Baha region, Saudi Arabia, was used as the control for comparison. For preparing wood particles, samples were debarked (to avoid the desirable effect of bark during determination), airdried, cut, ground, and screened. Particles that passed through a 20 mesh sieve and were retained on a 40 mesh were used to determine the fuel characteristics of wood. However, particles that passed through a $40 \mathrm{~mm}$ mesh and retained on a $60 \mathrm{~mm}$ mesh were used for the chemical, ultimate, and proximate analyses of wood.

\section{Chemical analysis of wood}

Based on the oven-dried weight, the percentage of the total and benzene-alcohol extracts of the wood samples $(-40 /$ +60 mm mesh) were determined using the methods outlined in the ASTM standard. Using the free-extractives 
meal, the contents of cellulose, hemicelluloses, and lignin were determined according to the ASTM D-1037 standard [29]. For ash content determination, approximately $2 \mathrm{~g}$ of oven-dried wood particles $(-40 /+60 \mathrm{~mm}$ mesh) were burned in a muffle furnace at $575 \pm 25^{\circ} \mathrm{C}$ for $6 \mathrm{~h}$. Ash content was calculated as a percentage based on the ovendry weight of the sample [29].

\section{Thermal behavior}

The thermal behavior of wood was investigated by thermogravimetric analysis using a thermo-gravimetric analyzer (TGA). Wood samples were heated in nitrogen at a rate of $10{ }^{\circ} \mathrm{C} \min ^{-1}$ up to $900{ }^{\circ} \mathrm{C}$ to assess the devolatilization of organic matter. Both curves of the percentage of weight loss versus temperature (TGA) and the derivative weight loss versus temperature (DTG) were determined and analyzed.

\section{Pyrolysis process}

The woody parts of the four species were chopped into small pieces and oven-dried at $103 \pm 5^{\circ} \mathrm{C}$ for $24 \mathrm{~h}$ in a cylindrical stainless steel reactor $(3.8 \mathrm{~cm}$ ID $\times 13 \mathrm{~cm}$ long), inside a muffle furnace. In the current study, slow pyrolysis using a temperature of $500{ }^{\circ} \mathrm{C}$ was selected as an indicative temperature for comparison of the charcoal properties of the invasive plants according to Lee et al. [30].

The reactor was sealed at one end, and the other end had a removable cover with $2 \mathrm{~mm}$ hole at the center to allow pyrolysis gases to escape [31]. The reactor was heated to a final temperature $\left(500{ }^{\circ} \mathrm{C}\right)$ under oxygen-limited conditions at the rate of $10{ }^{\circ} \mathrm{C} \mathrm{min}{ }^{-1}$ for $4.5 \mathrm{~h}$ measured from the time that the furnace reached the final temperature [32]. After the pyrolysis process, the specimens (reactor and charcoal) were allowed to cool to $100{ }^{\circ} \mathrm{C}$, and then cooled in a desiccator at room temperature of $25 \pm 3{ }^{\circ} \mathrm{C}$ prior to measurements. The charcoal yield was calculated as a percentage of the oven-dried weight of the samples before pyrolysis, and the charcoal samples were ground for further analysis. The fixed charcoal yield (FCY) was calculated using the following equation [33]:

FCY, $\%=\frac{\text { Charcoal yield } \times(100-\% \text { volatile matter }-\% \text { char ash })}{100-\% \text { wood ash }}$.

\section{Ultimate and proximate analysis}

Elemental contents as percentages of carbon (C), hydrogen $(\mathrm{H})$, and nitrogen $(\mathrm{N})$ for wood and charcoal were determined using a CHN analyzer (Perkin Elmer model
2400). The oxygen (O) content was calculated using the following equation: $\mathrm{O} \quad(\%)=100-(\mathrm{C}+\mathrm{H}+$ $\mathrm{N}+$ ash). The proximate analysis, including moisture, ash, and volatile matter (VM) contents in both wood and charcoal, were determined according to ASTM D1762 [34]. Fixed $\mathrm{C}$ content was calculated by subtracting the contents of moisture, ash, and VM from 100.

\section{Heating value}

On a dry weight basis and according to ASTM D 2015-85 [35], heating values (HV) of the wood and charcoal were determined for the three invasive plants and control. Approximately $1 \mathrm{~g}$ of oven-dried ground sample $(-20 /$ $+40 \mathrm{~mm}$ mesh) was pressed into pellets using a hydraulic pellet press and loaded into an oxygen bomb calorimeter (Parr model 6300). No correction was included in the HV calculations. Nine samples per species were combusted to estimate the HV. The fuel value index (FVI) was calculated using a modified method of Bhatt and Todaria [36]. The higher heating value (HHV) refers to the heating value determined by the calorimeter based on the ovendry weight. The lower heating value (LHV or HV) as received (ar) and dry ash-free fuel (daf) was calculated [15].

\section{Ranking of invasive plants}

Separately and overall, the wood and charcoal of the three invasive plants and control were rated based on the positive and/or negative impacts on the energy content and environmental impact [8]. The property was assigned a value between 1 and 4 , with 1 being the best and 4 being the worst. The rating was calculated as the sum of all values divided by the number of measured properties $(\boldsymbol{\Sigma} / 13$ for wood, $\Sigma / 10$ for charcoal, and $\Sigma / 23$ for both). If the difference between any two plants was not significant, we assigned them the same value.

\section{Statistical analysis}

Data were analyzed using a complete randomized design (CRD) to detect the statistical differences among the species. An analysis of variance (ANOVA) was used to detect the differences between them in all the measured properties. To test these differences, least significant differences at a 0.05 level of probability $\left(\mathrm{LSD}_{0.05}\right)$ were used. A correlation analysis was used to determine the relationship between the $\mathrm{HV}$ and each of the chemical constituents, and the ultimate and proximate analyses. 


\section{Results and discussions}

\section{Chemical composition of wood}

The chemical composition of wood and/or lignocellulosic materials accurately determines their suitability for energy production. However, to understand the behavior of the biomass and its expected effects on the energy products from the pyrolysis process, the biomass should be characterized [37]. The statistical analysis showed that the chemical constituents between the four different wood samples were significantly different $(P<0.01)$. The average values of the chemical composition are shown in Table 1.

The content of total extractives (TEC) for the three invasive plants ranged from $15.8 \%$ (C. procera) to $19.6 \%$ ( $P$. australis), which was much higher than that of A.tortilis (13.3\%), softwood, and hardwood species. The higher TEC may be attributed to their open anatomical structure [17] and/or the environmental conditions, where the plants were growing [38]. The highest cellulose content was observed in wood samples of P. australis (52.8\%), which is higher than that of $A$. tortilis (46.7\%). However, the cellulose content of $R$. stricta was lower than A. tortilis, the softwoods, and hardwoods. The hemicellulose content fell in the range of that of either softwood or hardwood species, at 26.3 and $35.5 \%$ for $C$. procera and $R$. stricta, respectively, which was higher than that of $A$. tortilis $(21.2 \%)$. The lignin contents were in the range of commercial wood (softwood and hardwood) and ranged from $19.3 \%$ (P. australis) to $28.3 \%$ (C. procera), which was lower than that of A. tortilis (32.0\%).

The invasive plants used in the present study are characterized by higher total extractive and lower lignin contents. However, we expected that higher extractives of these plants will not increase the energy output, because there are no significant differences between them in the benzene-alcohol extractive (ranged from 5.2 to $7.1 \%$,
Table 1), indicating that most of the total extractives are soluble in water, which have little effect on the energy output [15]. Nasser et al. [15] reported that the correlation between total extractives and heating values was not significant, while the correlation between heating values and benzene-alcohol extractives was significant. The little effect of extractives soluble in water on the energy output is due to its chemical compositions, i.e., sugars, which have lower heating values.

These results agreed with the chemical composition reported by Nasser et al. [20] for $C$. procera, and partially agreed with Jiménez et al. [39] for $P$. australis. The chemical composition of the three invasive plants used was similar to that of commercial wood species, i.e., softwood and hardwood [40], as well as other non-woody plants [41]. Accordingly, based on their chemical composition, they could be suitable for energy production.

\section{Ultimate and proximate analyses of wood}

As shown in Table 2, $\mathrm{C}$ content of wood ranged between 46 (C. procera) and $50 \%$ (R. stricta), whereas $\mathrm{H}$ content ranged from 5.9 to $6.1 \%$ for $P$. australis and $R$. stricta, respectively. The highest content of $\mathrm{N}(0.75 \%)$ was recorded in $R$. stricta and the lowest in $P$. australis $(0.14 \%)$. Combustion of wood mainly emitted water, $\mathrm{CO}_{2}$, and nitrogen oxides $\left(\mathrm{NO}_{x}\right)$ to the atmosphere. The higher the $\mathrm{N}$ content, the higher the emission of $\mathrm{NO}_{x}$ gases, which has a negative impact on human health and the environment [8]. Although, $\mathrm{N}$ contents in all samples were low $(0.14-0.75 \%)$, especially compared with coal, $1.4 \%$ [42], the $\mathrm{N}$ content of $R$. stricta should be taken into consideration if used for energy production. It is expected that during the burning of these invasive plants, $\mathrm{NO}_{x}$ release will be low. Accordingly, using these plants for energy production could have a relatively low impact on the environment due to their low $\mathrm{N}$ content [37, 43]. The

Table 1 Wood chemical composition $(\mathrm{db}, \%)$ of the invasive plants compared with that of the indigenous wood species

\begin{tabular}{|c|c|c|c|c|c|}
\hline Species & Total extractives ${ }^{\mathrm{a}}$ & $\mathrm{BAE}^{\mathrm{b}}$ & Cellulose $^{\mathrm{c}}$ & Hemicelluloses ${ }^{\mathrm{c}}$ & $\operatorname{Lignin}^{c}$ \\
\hline Calotropis procera & $17.36^{\mathrm{B}} \pm 1.2$ & $6.85^{\mathrm{A}} \pm 0.7$ & $45.50^{\mathrm{B}} \pm 1.4$ & $26.25^{\mathrm{C}} \pm 0.3$ & $28.25^{\mathrm{B}} \pm 1.6$ \\
\hline Phragmites australis & $19.56^{\mathrm{A}} \pm 1.0$ & $5.23^{\mathrm{B}} \pm 0.7$ & $52.76^{\mathrm{A}} \pm 1.1$ & $27.97^{\mathrm{B}} \pm 1.3$ & $19.27^{\mathrm{C}} \pm 0.2$ \\
\hline Rhazya stricta & $15.80^{C} \pm 0.3$ & $6.07^{\mathrm{AB}} \pm 0.5$ & $38.54^{\mathrm{C}} \pm 1.8$ & $35.46^{\mathrm{A}} \pm 0.3$ & $26.00^{\mathrm{B}} \pm 2.1$ \\
\hline Acacia tortilis & $13.32^{\mathrm{D}} \pm 0.2$ & $7.12^{\mathrm{A}} \pm 0.6$ & $46.74^{\mathrm{B}} \pm 0.7$ & $21.24^{\mathrm{D}} \pm 1.1$ & $32.02^{\mathrm{A}} \pm 1.4$ \\
\hline Hardwood & $2-6$ & - & $45-50$ & $15-35$ & $18-25$ \\
\hline Softwood & $2-8$ & - & $45-50$ & $20-32$ & $25-35$ \\
\hline Lopez et al. [40] & $2.4-6.8$ & - & $34-52$ & $15-26$ & $28-31$ \\
\hline
\end{tabular}

Means with the same capital letters in columns are not significantly different according to least significant differences (LSD) test

${ }^{a}$ As a percentage of oven-dry weight

${ }^{b}$ BAE: benzene-alcohol was done using a mixture of them 2:1 v/v, respectively, for $4 \mathrm{~h}$

c As a percentage of free-extractive oven-dry weight 
Table 2 Ultimate and proximate analyses and fuel properties of the invasive species compared with that of Acacia tortilis

\begin{tabular}{lllll}
\hline Property & \multicolumn{3}{l}{ Species } & \\
\cline { 2 - 3 } & C. procera & P. australis & R. stricta & A. tortilis \\
\hline Ultimate analysis & & & & \\
Carbon (C) & $45.81^{\mathrm{C}} \pm 0.3$ & $45.69^{\mathrm{C}} \pm 0.1$ & $49.91^{\mathrm{A}} \pm 0.1$ & $46.64^{\mathrm{B}} \pm 0.2$ \\
Hydrogen (H) & $6.03^{\mathrm{A}} \pm 0.2$ & $5.92^{\mathrm{A}} \pm 0.1$ & $6.13^{\mathrm{A}} \pm 0.1$ & $6.08^{\mathrm{A}} \pm 0.04$ \\
Nitrogen (N) & $0.31^{\mathrm{B}} \pm 0.1$ & $0.14^{\mathrm{C}} \pm 0.1$ & $0.75^{\mathrm{A}} \pm 0.1$ & $0.38^{\mathrm{B}} \pm 0.1$ \\
Oxygen (O) & $44.59^{\mathrm{B}} \pm 0.3$ & $46.06^{\mathrm{A}} \pm 0.2$ & $41.68^{\mathrm{C}} \pm 0.2$ & $44.95^{\mathrm{B}} \pm 0.2$ \\
Proximate analysis & & & \\
Moisture & $3.49 \pm 0.1$ & $2.92 \pm 0.1$ & $3.06 \pm 0.02$ & $3.54 \pm 0.1$ \\
Ash & $3.26^{\mathrm{A}} \pm 0.03$ & $2.19^{\mathrm{B}} \pm 0.2$ & $2.03^{\mathrm{C}} \pm 0.3$ & $1.95^{\mathrm{C}} \pm 0.01$ \\
Volatile matter & $83.86^{\mathrm{A}} \pm 0.6$ & $77.10^{\mathrm{C}} \pm 0.3$ & $80.63^{\mathrm{B}} \pm 0.5$ & $80.37^{\mathrm{B}} \pm 0.3$ \\
Fixed carbon & $9.39^{\mathrm{C}} \pm 0.7$ & $17.79^{\mathrm{A}} \pm 0.3$ & $14.28^{\mathrm{B}} \pm 0.7$ & $14.14^{\mathrm{B}} \pm 0.3$ \\
Fuel properties & & & & \\
HHV (db, MJ/kg) & $18.77^{\mathrm{C}} \pm 0.3$ & $18.52^{\mathrm{C}} \pm 0.2$ & $19.79^{\mathrm{A}} \pm 0.3$ & $19.29^{\mathrm{B}} \pm 0.3$ \\
HHV (daf, MJ/kg) & $19.38^{\mathrm{B}} \pm 0.2$ & $18.93^{\mathrm{C}} \pm 0.1$ & $20.09^{\mathrm{A}} \pm 0.2$ & $19.67^{\mathrm{B}} \pm 0.2$ \\
FVI & 554 & 825 & 1210 & 1521 \\
\hline
\end{tabular}

Mean values of nine samples

Means with the same letters in rows are not significantly different according to least significant differences (LSD) test

$\mathrm{O}(\%)=100-(\mathrm{C}+\mathrm{H}+\mathrm{N}+$ ash $)$ according to Pereira et al. [47]

$H H V$ Higher heating value, $d b$ dry weight basis, $d a f$ dry weight ash-free, FVI Fuel value index oxygen content ranged from $42 \%$ (R. stricta) to $46 \%(P$. australis). $R$. stricta wood had the highest contents of $\mathrm{C}, \mathrm{H}$, and $\mathrm{N}$, which were higher than those of A. tortilis. Furthermore, the elemental composition of the invasive plants fell in the range of woody biomasses [37, 40, 44], but was considerably lower than that of bituminous coal, $73.1 \%$ [42].

Increased $\mathrm{C}$ and $\mathrm{H}$ contents of biomass are preferable for energy production, whereas increased $\mathrm{N}$ content has a negative effect on the environment [8]. Therefore, it is expected that the energy output of $R$. stricta will be high compared with other invasive plants used in this study, but their negative impact on the environment will also be high.

From the proximate analysis, the volatile matter content (VMC) of the invasive plants ranged from $77.1 \%$ ( $P$. australis) to $83.9 \%$ (C. procera). These values fell in the range reported by Yang et al. [43] for common biomass (65-85\%) and by Telmo et al. [45] for woody biomass $(75-87 \%)$. However, they were much higher than that of coal, 35\% [42]. Therefore, the invasive plants studied were easy to ignite at a wide range of temperatures, including low temperatures [37]. The lowest ash content was observed in wood of $R$. stricta $(1.5 \%)$, whereas the highest ash content was observed in wood of $C$. procera $(3.3 \%)$. Ash content of wood is generally less than $1 \%$, but may reach up to $20 \%$ in some wood species. Although the ash content of the invasive plants fell in the range of the biomass reported by several authors [37, 44, 45], these contents may be make them less desirable as an alternative biomass fuel [15]. The fixed carbon content (FCC) ranged from 9.4 to $18 \%$ for $C$. procera and $P$. australis, respectively. These values are in agreement with the values of common biomass published by several authors worldwide, which ranged from 7 to $20 \%$ [37, 44, 45].

\section{Fuel properties of wood}

Table 2 shows that there were significant differences among the studied invasive plants compared to A. tortilis concerning measured fuel properties of wood. With the exception of $R$. stricta, the other two invasive plants had HV based on dry basis and dry ash basis lower than $A$. tortilis. The HVs (db) ranged from 18.5 ( $P$. australis) to $19.8 \mathrm{MJ} / \mathrm{kg}$ (R. stricta). The highest values of $\mathrm{HV}_{\mathrm{db}}$ and $\mathrm{HV}_{\text {daf }}$ were obtained in $R$. stricta; however, the lowest values were obtained in $P$. australis. The $\mathrm{HV}$ of the invasive plants fell in the range of typical wood biomass fuels published in the literature, i.e., 18-21 MJ/kg for four species in the Mediterranean area [37], 18-19 MJ/kg for seven vine varieties in Saudi Arabia [15], 18-20 MJ/kg for four species of waste wood in Spain [40], 18-21 MJ/kg for 17 wood species in Portugal [44], 18.7-19.1 MJ/kg for five species of African fuelwood [8], and 18.6-19.7 MJ/kg for seven Acacia species in Riyadh [46]. However, the HVs of the invasive plants were greater than that of some biomass fuels published in the literature, which were $13-17 \mathrm{MJ} / \mathrm{kg}$ 
for six biomass residues in Indonesia [47], and 17-18 MJ/ $\mathrm{kg}$ for five date palm cultivars in Saudi Arabia [17]. Consequently, the wood of the invasive plants was considered a promising energy source.

The FVI of the invasive plants ranged from 554 ( $C$. procera) to 1210 (R. stricta) and were lower than that of $A$. tortilis (1521). The lower values of FVI may be attributed to increased ash content, the most important variable adversely affecting the FVI. Nasser et al. [15] found low FVI values for vine stalks ranged from 225 to 508, whereas Kataki and Konwer [48] reported a wide range of FVI from 369 (Litsea polyantha) to 2089 (A. nilotica).

\section{Thermal properties}

TGA and DTG are the best tools to determine the thermal behavior of biomass samples, and they are important factor for the reactor design during the pyrolysis process [49]. TGA provides the weight loss of the sample versus temperature, whereas DTG provides the rate of weight loss. The TGA curves (Fig. 1) show that the thermal decomposition of the wood of the invasive plants occurred below $500{ }^{\circ} \mathrm{C}$. The DTG curves showed a single peak for $C$. procera and three peaks for A. tortilis, $R$. stricta, and $P$. australis. This indicated that $C$. procera is thermally simpler than the other species.

The main chemical constituents of the woody biomass are cellulose, hemicellulose, and lignin. The conspicuous two peaks in Fig. 1 may possibly be assigned as hemicellulose and cellulose. In some literatures, the assignment is avoided, because thermal decomposition generally includes multiple reactions, being interactive each other. However, Manasray and Ghaly [50] and El May et al. [51] dared to assign a peak with a shoulder as overlap of hemicellulose and cellulose. Following their assignment, here, we assume that the three main fractions at $150-350{ }^{\circ} \mathrm{C}, 275-350{ }^{\circ} \mathrm{C}$, and $250-500{ }^{\circ} \mathrm{C}$ correspond to hemicellulose, cellulose, and lignin, respectively. On the basis of this assumption, we try to discuss the thermal properties of the species relating to their components. As shown in Table 3 and Fig. 1, three distinct peaks of weight loss were obtained during pyrolysis. The first peak was located at temperatures ranging from $72\left(C\right.$. procera) to $86{ }^{\circ} \mathrm{C}$ (A. tortilis) corresponding to moisture evaporation from wood samples, which confirms that the moisture content of the samples was approximately $3-4 \%$ (Table 3 ). The second peak corresponded to the thermal decomposition of hemicellulose, and ranged from 320 (P. australis) to $345{ }^{\circ} \mathrm{C}(R$. stricta). For $C$. procera, the overlapping of the decomposition temperatures of hemicellulose and cellulose was occurred and this observation was reported previously $[50,51]$. The third peak occurred at temperatures ranging from 372 ( $P$. australis) to $400{ }^{\circ} \mathrm{C}(R$. stricta) and corresponded to the decomposition of cellulose. These results are consistent with the data on different types of biomasses [43, 47, 49, 52, 53]. For lignin decomposition, there was no peak for any of the species studied, which may be because of its wide range of decomposition temperatures from 150 to $900{ }^{\circ} \mathrm{C}$ without a sharp weight-loss peak [52-54].

Table 3 shows the devolatilization data of the wood of the invasive plants and A. tortilis, which were extracted from the curves of TGA and DTG according to Salaheldeen et al. [49] and Chen and Kuo [52]. Although the wood of the three invasive plants used in the present study has thermal behavior similar to those of the A. tortilis wood for bioenergy production (Table 3), there were some
Fig. 1 Thermo-gravimetric analysis (TGA) and derivative thermo-gravimetric (DTG) curves of the three invasive plants and Acacia tortilis at a heating rate of $10^{\circ} \mathrm{C} \mathrm{min}{ }^{-1}$ in nitrogen

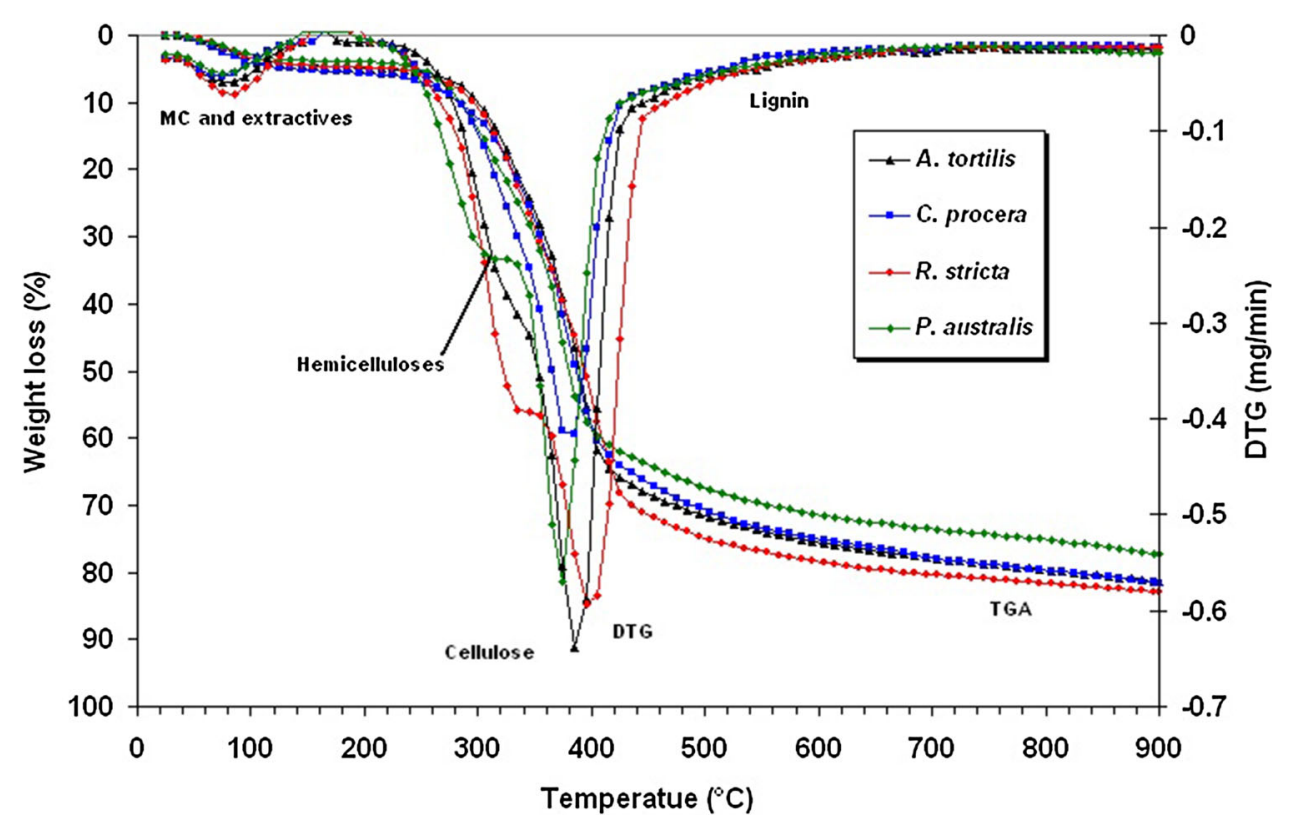


Table 3 Devolatilization of the invasive plants and Acacia tortilis

\begin{tabular}{|c|c|c|c|c|c|c|c|c|}
\hline \multirow[t]{2}{*}{ Species } & \multirow{2}{*}{$\begin{array}{l}T_{\mathrm{i}} \\
\left({ }^{\circ} \mathrm{C}\right)\end{array}$} & \multicolumn{3}{|c|}{ Peak temperature $\left({ }^{\circ} \mathrm{C}\right)$} & \multirow{2}{*}{$\begin{array}{l}\text { Temperature } \\
\text { of APZ }\left({ }^{\circ} \mathrm{C}\right)\end{array}$} & \multirow{2}{*}{$\begin{array}{l}T_{50} \\
\left({ }^{\circ} \mathrm{C}\right)\end{array}$} & \multirow{2}{*}{$\begin{array}{l}R_{50} \\
\left(\mathrm{wt} \% \mathrm{~min}^{-1}\right)\end{array}$} & \multirow{2}{*}{$\begin{array}{l}\text { Residue } \\
(\%)\end{array}$} \\
\hline & & $P_{\mathrm{MC}}$ & $P_{\mathrm{HEM}}$ & $P_{\mathrm{CEL}}$ & & & & \\
\hline C. procera & 221 & 72 & - & 382 & $235-405$ & 384 & 7.23 & 18.4 \\
\hline P. australis & 198 & 76 & 320 & 372 & $240-390$ & 379 & 7.40 & 22.7 \\
\hline R. stricta & 240 & 82 & 345 & 400 & $238-410$ & 393 & 6.32 & 17.0 \\
\hline A. tortilis & 255 & 86 & 330 & 388 & $280-410$ & 389 & 6.93 & 18.6 \\
\hline
\end{tabular}

These data were extracted from the thermo-gravimetric analysis (TGA) curve with a heating rate $10{ }^{\circ} \mathrm{C} \min ^{-1}$ in nitrogen

Bold values of $A$. tortilis for comparison

$T_{\mathrm{i}}$ is ignition temperature, WL is weight loss, $T_{50}$ is the temperature at the level of $50 \%$ weight loss, and $R_{50}$ is the rate of weight loss at $T_{50}, P_{\mathrm{MC}}, P_{\mathrm{HEM}}$, and $P_{\mathrm{CEL}}$ that are peak temperatures of moisture, hemicellulose, and cellulose, respectively

$T_{50}$ and $R_{50}$ according to Chen and Kuo [52]

Residue at $900{ }^{\circ} \mathrm{C}$ (ash and fixed carbon content)

$A P Z$ active pyrolysis zone differences. The percentage of residue (ash and charcoal) ranged from 17 ( $R$. stricta) to $23 \%$ ( $P$. australis). These differences may be attributed to the differences in the chemical composition of wood, especially ash and lignin contents or due to the combination of higher hemicellulose and lignin contents [55]. The initial ignition temperatures ( $\left.T_{\mathrm{i}}\right)$ of the invasive plants were lower than those of $A$. tortilis. The lowest $T_{\mathrm{i}}$ was recorded for $P$. australis $\left(198^{\circ} \mathrm{C}\right)$, whereas the highest one was obtained for $A$. tortilis $\left(255^{\circ} \mathrm{C}\right)$, indicating that the wood of the invasive plants was more reactive than that of A. tortilis. These differences may result from differences in the ultimate analysis and chemical constituents of the species studied [49, 56, 57].

At the end of active pyrolysis zone, the temperature differed between species and ranged from 390 (P. australis) to $410{ }^{\circ} \mathrm{C}$ (R. stricta). As shown in Table 3 , two indices, $T_{50}$ and $R_{50}$, were used to compare the weight loss among the invasive plants and A. tortilis according to Chen and Kuo [52]. The former is the temperature at $50 \%$ weight loss, while the latter is the rate of weight loss at $T_{50}$. The $T_{50}$ values ranges from $379{ }^{\circ} \mathrm{C}\left(P\right.$. australis) to $393{ }^{\circ} \mathrm{C}(R$. stricta). This indicates that the heated wood of these invasive plants up to $400{ }^{\circ} \mathrm{C}$ resulted in $>50 \%$ weight loss. The value of $R_{50}$ ranged between 6.3 (R. stricta) and $7.4 \mathrm{wt} \% \min ^{-1}$ ( $P$. australis). The $R_{50}$ value was relatively high for the three invasive species, implying that the intensity of weight loss of wood is relatively dramatic near $T_{50}$ [52]. Increasing $R_{50}$ for material indicates that the material is relatively active. This confirms the fact that the thermal decomposition of wood is characterized by a rapid loss in the second region [53]. As shown in Table 3, the values of $T_{\max }, C$. procera, and $P$. australis lost most of their volatile matter at lower temperatures than $A$. tortilis and $R$. stricta [37]. Accordingly, these results suggesting that the wood of $C$. procera and $P$. australis was more reactive than that of $R$. stricta and A. tortilis, because they had a maximum degradation rate and lower $T_{\max }$ of weight loss [49].

\section{Charcoal properties}

Three technologies in thermo-chemical conversion processes use biomass as a biorenewable source for bioenergy production, i.e., pyrolysis, gasification, and combustion [58]. The most efficient process is pyrolysis, which produces gases, bio-oil, and bio-char [49, 59].

Table 4 shows the charcoal characteristics produced from the three invasive plants compared with that of $A$. tortilis. The gravimetric charcoal yields ranged from $29(R$. stricta) to $31.7 \%$ (P. australis), which were lower than the value of $A$. tortilis (35\%). In addition, the same trend was observed with the amounts of FCY, which ranged from 21 to $26 \%$. These values fell in the range of charcoal produced from typical biomass and were close to the charcoal yields reported by Lee et al. [30] for six biomass residues at $500{ }^{\circ} \mathrm{C}$ ( $25 \%$ for bagasse to $41 \%$ for paddy straw), and ElJuhany and Aref [46] for seven acacia species at $450{ }^{\circ} \mathrm{C}$ (29\% for A. amplecips to $34 \%$ for A. asak).

Regarding the ultimate analysis, the $\mathrm{C}$ content of the charcoal ranged from 65 (C. procera) to $79 \%$ (R. stricta). However, there was no significant difference between the $\mathrm{C}$ content in charcoal of $R$. stricta and A. tortilis. However, these values were lower than those reported by Lee et al. [30] for six biomass residues (84-89\%). The highest $\mathrm{H}$ content was measured in $P$. australis $(3.1 \%)$, but was lower than the value of $3.2 \%$ in A. tortilis. The $\mathrm{N}$ content ranged from 0.42 ( $P$. australis) to $1.0 \%$ (R. stricta). Only the N content of $R$. stricta was lower than the value measured in A. tortilis $(0.54 \%)$. The $O$ content of the charcoal of the invasive plants ranged between 16.7 ( $P$. australis) and 27\% (C. procera), whereas that of A. tortilis was $16.5 \%$. All the $\mathrm{O}$ values in the three invasive plants were higher than that of A. tortilis. 
Table 4 Charcoal $^{\mathrm{a}}$ properties of the invasive plants compared with the char of Acacia tortilis

\begin{tabular}{lcccc}
\hline Property & Calotropis procera & Phragmites australis & Rhazya stricta & Acacia tortilis \\
\hline Yield & & & & \\
Gravimetric & $30.28^{\mathrm{BC}} \pm 0.6$ & $31.69^{\mathrm{B}} \pm 0.6$ & $28.98^{\mathrm{C}} \pm 1.3$ & $34.66^{\mathrm{A}} \pm 1.4$ \\
FCY & $21.37^{\mathrm{BC}} \pm 0.5$ & $22.58^{\mathrm{B}} \pm 0.4$ & $20.84^{\mathrm{C}} \pm 0.7$ & $26.14^{\mathrm{A}} \pm 1.2$ \\
Ultimate analysis & & & & \\
Carbon (C) & $65.33^{\mathrm{C}} \pm 1.2$ & $75.34^{\mathrm{B}} \pm 0.5$ & $78.90^{\mathrm{A}} \pm 0.7$ & $77.73^{\mathrm{A}} \pm 0.5$ \\
Hydrogen (H) & $2.86^{\mathrm{C}} \pm 0.1$ & $3.05^{\mathrm{B}} \pm 0.1$ & $2.99^{\mathrm{B}} \pm 0.02$ & $3.22^{\mathrm{A}} \pm 0.03$ \\
Nitrogen (N) & $0.63^{\mathrm{B}} \pm 0.1$ & $0.42^{\mathrm{C}} \pm 0.1$ & $1.00^{\mathrm{A}} \pm 0.02$ & $0.54^{\mathrm{B}} \pm 0.03$ \\
Oxygen (O) & $26.98^{\mathrm{A}} \pm 1.1$ & $16.56^{\mathrm{C}} \pm 0.4$ & $17.38^{\mathrm{B}} \pm 0.7$ & $16.52^{\mathrm{C}} \pm 0.6$ \\
Proximate analysis & & & & \\
Moisture & $1.29^{\mathrm{B}} \pm 0.3$ & $1.58^{\mathrm{B}} \pm 0.1$ & $0.92^{\mathrm{C}} \pm 0.1$ & $1.95^{\mathrm{A}} \pm 0.2$ \\
Ash & $4.20^{\mathrm{B}} \pm 0.2$ & $4.63^{\mathrm{A}} \pm 0.2$ & $3.73^{\mathrm{C}} \pm 0.2$ & $1.99^{\mathrm{D}} \pm 0.04$ \\
Volatile matter & $27.68^{\mathrm{A}} \pm 0.7$ & $25.70^{\mathrm{B}} \pm 0.2$ & $25.47^{\mathrm{B}} \pm 0.7$ & $24.24^{\mathrm{C}} \pm 0.4$ \\
Fixed carbon & $66.93^{\mathrm{D}} \pm 1.0$ & $68.09^{\mathrm{C}} \pm 0.1$ & $69.88^{\mathrm{B}} \pm 0.7$ & $71.82^{\mathrm{A}} \pm 0.6$ \\
Fuel characteristics & & & & \\
HHV (db, MJ/kg) & $25.68^{\mathrm{D}} \pm 0.5$ & $27.73^{\mathrm{C}} \pm 0.6$ & $28.93^{\mathrm{B}} \pm 0.2$ & $30.13^{\mathrm{A}} \pm 0.7$ \\
\hline
\end{tabular}

Means with the same superscript letters in rows are not significantly different according to least significant differences (LSD) test

$\mathrm{O}(\%)=100-(\mathrm{C}+\mathrm{H}+\mathrm{N}+$ ash $)$ according to Pereira et al. [47]

$F C Y$ fixed carbon yield, $H H V$ higher heating value, $d b$ dry weight basis

${ }^{\text {a }}$ Produced at $400{ }^{\circ} \mathrm{C}$ for $4 \mathrm{~h}$
The lowest charcoal ash content of the invasive plants was found in wood samples of $R$. stricta $(3.7 \%)$, whereas the highest value was obtained in $P$. australis (4.6\%), which was higher than that of A. tortilis $(2.0 \%)$. These values were lower than those reported by El-Juhany and Aref [46] for seven acacia species (4.5-7.0\%). Increased ash content from the biomass reduces its value as a fuel source [8].

Regarding the proximate analysis of the charcoal, the results in Table 4 showed the VMC on the charcoal produced by the invasive plants ranged from $25.5 \%$ (R. stricta) to $27.7 \%$ (C. procera), which were higher than the VMC of A. tortilis charcoal $(24.2 \%)$. The VMC values of the charcoal fell in the range of typical biomass (21-32\% [60]; $27-32 \%$ [46]; and 24-26\% [61]. The VMC in charcoal can vary from $<5$ to $40 \%$ [62]. High volatile charcoal is easy to ignite but may burn with a smoke flame, whereas low volatile charcoal is difficult to light and burns clearly. A good quality charcoal has a net VMC of about $30 \%$ [32]; however, Santos [63] reported that charcoal should have a VMC of $20-25 \%$ to be suitable for the steel industry. As a result, the VMC from the charcoal produced from the invasive plants indicated it is of high quality and is suitable for the steel industry.

The FCC of the charcoal ranged from 67 (C. procera) to $70 \%$ (R. stricta), which were lower than those obtained from charcoal of A. tortilis (72\%). The FCC values were similar to those from other wood species $(68-75 \%)$ [60] and $67-77 \%$ [62] and 68-75\% [60]). However, they were slightly higher than values reported by El-Juhany and Aref
[46] on seven acacia species (57-63\%), and slightly lower than those reported by Lopez et al. [40] (79-89\%).

According to the $\mathrm{HV}$ of the charcoal, the charcoal made from $R$. stricta $(29 \mathrm{db}, \mathrm{MJ} / \mathrm{kg})$ was the highest among the three invasive plants, but was lower than that of A. tortilis (30 db, MJ/kg). Despite having higher ash contents, the charcoal from the invasive plant species exhibited higher calorific values, similar to that of A. tortilis charcoal. HVs of the invasive plant charcoal were similar to or greater than those produced from woody biomass reported in the literature (26.9-31.1 MJ/kg) [60], 27.6-29.4 MJ/kg) [46], but lower than the values of $30-35 \mathrm{MJ} / \mathrm{kg}$ reported by Lopez et al. [40].

\section{Ranking of invasive plants}

Overall, compared with the wood of $A$. tortilis, the results shown in Table 5 indicated that the wood of $R$. stricta and $P$. australis is suitable for energy production. Concerning the problems with the expected $\mathrm{N}$ oxide emissions, the charcoal from $P$. australis has a lower nitrogen content $(0.42 \%)$ than that of $R$. stricta $(1.0 \%)$.

\section{Conclusions}

The results showed that the content of total extractives for the three invasive plants were higher than that of A. tortilis, softwood and hardwood species. The highest cellulose 
Table 5 Rating $^{\text {a }}$ of the three invasive plants regarding all determined properties

\begin{tabular}{|c|c|c|c|c|}
\hline \multirow[t]{2}{*}{ Property } & \multicolumn{4}{|c|}{ Invasive species } \\
\hline & C. procera & P. australis & R. stricta & A. tortilis \\
\hline Lignin content & 2 & 3 & 2 & 1 \\
\hline Ash content & 3 & 2 & 1 & 1 \\
\hline Volatile matter & 1 & 3 & 2 & 2 \\
\hline Fixed carbon content & 3 & 1 & 2 & 2 \\
\hline Carbon content & 3 & 3 & 1 & 2 \\
\hline Nitrogen content & 2 & 1 & 3 & 2 \\
\hline Oxygen content & 2 & 3 & 1 & 2 \\
\hline Heating value & 3 & 3 & 1 & 2 \\
\hline Fuel value index & 4 & 3 & 2 & 1 \\
\hline Rating value (wood) & 3 & 2 & 1 & 1 \\
\hline \multicolumn{5}{|l|}{ Charcoal } \\
\hline Heating value & 4 & 3 & 2 & 1 \\
\hline Char yield & 2 & 2 & 3 & 1 \\
\hline Carbon content & 3 & 2 & 1 & 1 \\
\hline Hydrogen content & 3 & 2 & 2 & 1 \\
\hline Nitrogen content & 3 & 1 & 4 & 2 \\
\hline Oxygen content & 3 & 1 & 2 & 1 \\
\hline Moisture content & 2 & 2 & 1 & 3 \\
\hline Volatile matter & 3 & 2 & 2 & 1 \\
\hline Fixed carbon content & 4 & 3 & 2 & 1 \\
\hline Ash content & 2 & 4 & 3 & 1 \\
\hline Rating value & 3 & 2 & 2 & 1 \\
\hline Overall rating value & 4 & 3 & 2 & 1 \\
\hline
\end{tabular}

Bold values are the rating values of wood, charcoal and overall, respectivelly

${ }^{\text {a }}$ Based on Munalula and Meincken [8] content was observed in wood samples of $P$. australis, which was higher than the value of A. tortilis. Hemicelluloses and lignin contents were between that of softwood and hardwood species. The invasive plants used in the present study were characterized by higher total extractive and lower lignin contents. With the exception of R. stricta, the other two invasive plants had HVs lower than that of $A$. tortilis.

The highest and lowest values of $\mathrm{HV}_{\mathrm{db}}$ and $\mathrm{HV}_{\mathrm{daf}}$ were obtained in $R$. stricta and $P$. australis, respectively. The $\mathrm{HV}$ of the invasive plants falls in the range of typical wood biomass fuels published in the literature. The highest and lowest $\mathrm{N}$ contents was recorded in $R$. stricta and P. australis, respectively, indicating a negative effect on the environment. Therefore, it is expected that the energy output of $R$. stricta will be high compared with other invasive plants used in this study, but their negative impact on the environment will be also high. The gravimetric charcoal and amounts of fixed $\mathrm{C}$ yields were higher in $P$. australis, but lower in A. tortilis. The fixed $\mathrm{C}$ content of the charcoal was higher in $R$. stricta, which was lower than those obtained from A. tortilis. VMC from the charcoal made from invasive plants was higher in $C$. procera, which was higher than that of A. tortilis.

The utilization of invasive plants as alternative sources for energy production could be an innovative management technique for the control of these species. The wood of the invasive plants could be fundamental in meeting the shortage in wood supply. Thus, it may be concluded that these invasive plants could be used to effectively produce industrial grade charcoal.

Acknowledgements The authors would like to extend their sincerest appreciation to the Deanship of Scientific Research at King Saud University for the funding of this research through the Research Group Project \# RGP-VPP-226.

\section{Compliance with ethical standards}

Conflict of interest The authors declare no conflict of interest.

\section{References}

1. Rejmánek M (1999) Invasive plant species and invisible ecosystems. In: Sandlund OT, Schei PJ, Viken A (eds) Invasive 
species and biodiversity management. Kluwer Academic Publishers, Dordrecht, pp 79-102

2. Pimentel D, McNair S, Janecka J, Wightman J, Simmonds C, O'Connell C, Wong E, Russel L, Zern J, Aquino T, Tsomondo T (2001) Economic and environmental threats of alien plant, animal, and microbe invasions. Agric Ecosyst Environ 84:1-20

3. Baruch Z, Patisson RR, Goldstien G (2000) Response to light and water availability of four invasive Melastomataceae in the Hawaiian Islands. Int J Plant Sci 161:107-118

4. Leal LC, Meiado MV, Lopes AV, Leal IR (2013) Germination responses of the invasive Calotropis procera (Ait.) $\mathrm{R}$. Br. (Apocynaceae): comparisons with seeds from two ecosystems in northeastern Brazil. An Acad Br Ciên 85:1025-1034

5. Menge EO, Stobo-Wilson A, Oliveira SLJ, Lawes MJ (2016) The potential distribution of the woody weed Calotropis procera (Aiton) W.T. Aiton (Asclepiadaceae) in Australia. Rangel J 38:35-46

6. Fredrick K (2000) Need and effectiveness of control measures on Phragmites australis in restoration situations. Restor Reclam Rev 6:1-6

7. Al-Qarawi AA, Abdullah EF, Al-Shahrani TS, Alzain MN (2014) Allelopathic impact of Rhazya stricta Dence and Artemisia monosperma Delile on plant growth and the structural colonization of AM fungi. Arab Gulf J Sci Res 32:41-50

8. Munalula F, Meincken M (2009) An evaluation of South African fuelwood with regards to calorific value and environmental impact. Biomass Bioenergy 33:415-420

9. Tessema YA (2012) Ecological and economic dimensions of the paradoxical invasive species-Prosopis juliflora and policy challenges in Ethiopia. J Econ Sustain Dev 3:62-70

10. Ye XP, Julson J, Kuo M, Womac A, Myers D (2007) Properties of medium density fiberboards made from renewable biomass. Bioresour Technol 98:1077-1084

11. Cubars E, Noviks G (2012) Evaluation of reed resources in Latvia and analysis of its use for energy production. J Environ Biol 33:387-392

12. Pesevski MD, Lliev BM, Zivkovic DL, Popovska VT, Srbinoska MA, Filiposki BK (2010) Possibilities for utilization of tobacco stems for production of energetic briquettes. J Agric Sci 55:45-54

13. Salleh F, Samsuddin R, Husin M (2011) Bio-fuel source from combination feed of sewage and rice waste. International Conference on Environment Science and Engineering IPCBEE. IACSIT Press, Singapore, pp 68-72

14. Ismaila A, Zakari IY, Nasiru R, Tijjani RI, Abdullahi I, Garba NN (2013) Investigation on biomass briquettes as energy source in relation to their calorific values and measurements of their total carbon and elemental contents for efficient biofuel utilization. Adv Appl Sci Res 4:303-309

15. Nasser RA, Salem MZM, Al-Mefarrej HA, Abdel-Aal MA, Soliman SS (2014) Fuel characteristics of vine prunings (Vitis vinifera L.) as a potential source for energy production. Bioresources 9:482-496

16. Babiker ME, Aziz AR, Yusup MH, Abakar M (2013) Pyrolysis characteristics of Phoenix dactylifera date palm seeds using thermo-gravimetric analysis (TGA). Int J Environ Dev 4:521-524

17. Nasser RA (2014) An evaluation of the use of midribs from common date palm cultivars grown in Saudi Arabia for energy production. Bioresources 9:4343-4357

18. Boutraa $T$ (2010) Effects of water stress on root growth, water use efficiency, leaf area and chlorophyll content in the desert shrub Calotropis procera. J Int Environ Appl Sci 5:124-132

19. Khristova P (1995) Soda-anthraquinone pulping of hibiscus Sabdariffa (karkadeh) and Calotropis procera from Sudan. Bioresour Technol 53:67-72
20. Nasser RA, Al-Mefarrej HA, Khan PR, Alhafta KH (2012) Technological properties of Calotropis procera (Ait) wood and its relation to utilizations. Am Eur J Agric Environ Sci 12:5-16

21. Chaudhary SA (2000) Flora of the Kingdom of Saudi Arabia. In: Ministry of agriculture and water (Part 2). Riyadh, Saudi Arabia, p 542

22. Baeshen NA, Lari SA, Aldoghaither HA, Elkady AI (2010) Biochemical evaluation of the effect of Rhazya stricta aqueous leaves extract in liver and kidney functions in rats. Nat Sci $8: 136-142$

23. Adel E, Mohamed EA, Attia AO, El Dessoky DS (2012) In vitro multiplication of the important medicinal plant, harmal (Rhazya stricta Decne). J Med Plant Res 6:3586-3590

24. Assaeed AM, Al-Doss AA (1997) Allelopathic effects of Rhazya stricta on seed germination of some range plant species. Ann Agric Sci Ain Shams Univ Cairo 42:159-167

25. Kask Ü, Kask L, Link S (2013) Combustion characteristics of reed and its suitability as a boiler fuel. Mires Peat 13:1-10

26. Al-Taisan WA (2009) Suitability of Using Phragmites australis and Tamarix aphylla as vegetation filters in industrial areas. Am J Environ Sci 5:740-747

27. Saltonstall K (2002) Cryptic invasion by a non-native genotype of Phragmites australis into North America. Proc Nat Acad Sci USA 99:2445-2449

28. Derr JF (2008) Common reed (Phragmites australis) response to moving and herbicide application. Invasive Plant Sci Manag $1: 12-16$

29. ASTM D-1037 (1989) Standard test method of evaluating the properties of wood-based fiber and particleboard panel materials. American Society for Testing and Materials, Philadelphia, p 1062

30. Lee Y, Park J, Ryu C, Gang KS, Yang W, Park YK, Jung J, Hyun S (2013) Comparison of biochar properties from biomass residues produced by slow pyrolysis at $500{ }^{\circ} \mathrm{C}$. Bioresour Technol 148:196-201

31. Alhamed Y (2006) Activated carbon from dates' stone by $\mathrm{ZnCl}_{2}$ activation. JKAU Eng Sci 17:75-100

32. Pereira BL, Carneiro AC, Carvalho AM, Colodette JL, Oliveira AC, Fontes MP (2013) Influence of chemical composition of Eucalyptus wood on gravimetric yield and charcoal properties. Bioresources 8:4574-4592

33. Oyedun AO, Lam KL, Hui CW (2012) Charcoal production via multistage pyrolysis. Chin J Chem Eng 20:455-460

34. ASTM D-1762-84 (1989) Standard test methods for chemical analysis of wood charcoal. American Society for Testing and Materials, Philadelphia, pp 569-571

35. ASTM D-2015 (1987) Standard test method for gross heating value of coal and coke by sdiabatic bomb calorimeter. American Society for Testing and Materials, Philadelphia

36. Bhatt BP, Todaria NP (1992) Fuelwood characteristics of some Indian mountain species. For Ecol Manag 47:363-366

37. Gómez N, Rosasa JG, Cara J, Martínez O, Alburquerque JA, Sánchez ME (2016) Slow pyrolysis of relevant biomasses in the Mediterranean basin. Part 1. Effect of temperature on process performance on a pilot scale. J Clean Prod 120:181-190

38. Khiari R, Mauret E, Belgacem MN, Mhemmi F (2011) Tunisian date palm rachis used as an alternative source of fibres for papermaking applications. Bioresources 6:265-281

39. Jiménez LA, Rodríguez A, Pérez A, Serrano L (2008) Alternative raw materials and pulping process using clean technologies. Ind Crop Prod 28:11-16

40. Lopez FA, Centeno TA, Garcia-Daz I, Alguacil FJ (2013) Textural and fuel characteristics of the chars produced by the pyrolysis of waste wood, and the properties of activated carbons prepared from them. J Anal Appl Pyrolysis 104:551-558 
41. Nasser RA, Al-Mefarrej HA (2011) Midribs of date palm as a raw material for wood-cement composite industry in Saudi Arabia. World Appl Sci J 15:1651-1658

42. McKendry P (2002) Energy production from biomass (part 1): overview of biomass. Bioresour Technol 83:37-46

43. Okoroigwe EC, Saffron CM (2012) Determination of bio-energy potential of palm kernel shell by physicochemical characterization. Niger J Technol 31:329-335

44. Yang YB, Ryu C, Khor A, Yates NE, Sharifi VN, Swithenbank J (2005) Effect of fuel properties on biomass combustion. Part II. Modelling approach-identification of the controlling factors. Fuel 84:2116-2130

45. Telmo C, Lousada J, Moreira N (2010) Proximate analysis, backwards stepwise regression between gross calorific value, ultimate and chemical analysis of wood. Bioresour Technol 101:3808-3815

46. El-Juhany LI, Aref IM (2003) Properties of charcoal produced from some endemic and exotic acacia species grown in Riyadh, Saudi Arabia. J Adv Agric Res 8:695-704

47. Pereira CR, Kaal J, Arbestain MC, Lorenzo PR, Aitkenhead W, Hedley M, Macias F, Hindmarsh J, Macia-Agullo JA (2011) Contribution to characterization of biochar to estimate the labile fraction of carbon. Org Geochem 42:1331-1342

48. Kataki R, Konwer D (2001) Fuelwood characteristics of some indigenous woody species of north-east India. Biomass Bioenergy 20:17-23

49. Salaheldeen M, Aroua MK, Mariod AA, Cheng SF, Abdelrahman MA (2014) An evaluation of Moringa peregrina seeds as a source for bio-fuel. Ind Crop Prod 61:49-61

50. Mansaray KG, Ghaly AE (1998) Thermal degradation of rice husks in nitrogen atmosphere. Bioresour Technol 65:13-20

51. El may Y, Jeguirim M, Dorge S, Trouvé G, Said R (2011) Thermogravimetric analysis and kinetic study on palm of Phoenix dactylifera L. Seventh Mediterranean Combustion Symposium, Part Reaction Kinetics of Combustion, MCS 7:1-9, Chia Laguna, Cagliari, Sardinia, Italy, September 11-15, 2011

52. Chen WH, Kuo PC (2010) A study on torrefaction of various biomass materials and its impact on lignocellulosic structure simulated by a thermogravimetry. Energy $35: 2580-2586$
53. Abed I, Paraschiv M, Loubar K, Zagrouba F, Tazerout M (2012) Thermogravimetric investigation and thermal conversion kinetics of typical North African and Middle Eastern lignocellulosic wastes. Bioresources 7:1200-1220

54. Huang S, Wu Q, Zhou D, Huang R (2015) Thermal decomposition properties of materials from different parts of corn stalk. Bioresources 10:2020-2031

55. Alwani MS, Abdul Khalil HP, Sulaimans O, Islam MN, Dungani R (2014) An approach to using agricultural wastes fibers in biocomposites applications: thermogravimetric analysis and activation energy study. Bioresources 9:218-230

56. Munir S, Daood SS, Nimmo W, Cunliffe AM, Gibbs BM (2009) Thermal analysis and devolatilization kinetics of cotton stalk, sugar cane bagas and shea meal under nitrogen and air atmosphere. Bioresour Technol 100:1413-1418

57. Demirbas MF, Balat M, Balat H (2009) Potential contribution of biomass to the sustainable energy development. Energy Convers Manag 50:1746-1760

58. Alburquerque JA, Sanchez ME, Mora M, Barron V (2016) Slow pyrolysis of relevant biomasses in the Mediterranean basin. Part 2. Char characterisation for carbon sequestration and agricultural uses. J Clean Prod 120:191-197

59. Nisgoski S, Magalhaes WLE, Batista FRR, Franca RF, de Muniz GIB (2014) Anatomical and energy characteristics of charcoal made from five species. Acta Amazonica 44:367-372

60. Pereira BL, Oliveira AC, Carvalho AM, Santos LC, Vital BR (2012) Quality of wood and charcoal from Eucalyptus clones for ironmaster use. Int J For Res 2012:1-8

61. Hindi SS (2012) Effect of wood material and pyrolytic conditions on biocarbon production. Int J Mod Eng Res 2:1386-1394

62. Food and Agriculture Organization of the United Nations-FAO (1985) Industrial charcoal making, FAO Forestry Paper No. 63, FAO, Rome

63. Santos MAS (2008) Quality parameters of charcoal for use in blast furnaces. In: Proceedings of the National Forum on Charcoal, vol 1. UFMG, Belo Horizonte, Brazil 